\title{
Microorganisms of various ecological-trophic groups in the saline ground waters of Primorsky Region (distribution, number, participation in accumulation of microelements)
}

\author{
Elena Lebedeva ${ }^{1, *}$, Georgy Chelnokov ${ }^{1}$, Ivan Bragin ${ }^{1}$, and Natalia Kharitonova $^{2}$ \\ ${ }^{1}$ Far Eastern Geological Institute, Far Eastern Branch of Russian Academy of Science, Vladivostok, \\ Russia \\ ${ }^{2}$ Lomonosov Moscow State University, Geological department, GSP-1, Moscow, Russia
}

\begin{abstract}
A small number of ecological-trophic groups of bacteria are noted in saline groundwater's $(30-50 \mathrm{~g} / \mathrm{L})$. The obtained data show, that thionic and halophilic forms of saprophytic bacteria dominated, developing in presence of $10 \% \mathrm{NaCl}$. Among saprophytic microorganisms, rod-shaped forms of the genus Microbacterium $s p$. significantly dominated. A significant accumulation of $\mathrm{Cu}, \mathrm{Co}$ and light REEs by brine microbial communities is shown.
\end{abstract}

\section{Introduction}

The Rechitsa saline groundwater manifestation is located in the coastal area of Sukhodol Bay in the valley of the Sukhodol River [1,2]. The investigation of the groundwater in Sukhodol Bay area was launched in 2007. The first results describing the groundwater geochemistry were reflected in [1]. Boreholes drilled with a depth of more than $500 \mathrm{~m}$, allowed to discover a unique type of water, unknown in Primorye previously.

Saline groundwaters of $\mathrm{Cl}-\mathrm{Ca}$ or $\mathrm{Cl}-\mathrm{Na}-\mathrm{Ca}$ types are the habitat of extremophilic microorganisms. High concentration of salts contributes to preservation of relict microbial community inside them. Bacteria in groundwater play a great role in geochemical circulation of substances and are an important biotic factor. They actively impact on chemical composition of deep waters, mineral formation and metamorphism of rocks. Therefore, the study of microorganisms living in extremely saline groundwater is of particular relevance. Despite long-term observations of temperature and chemical composition of brines [1-4], there is no information about the microorganisms inhabiting them. In this regard, the aim of this work was to study the distribution, number, composition of various ecological-trophic groups of bacteria, as well as the participation of microbial communities in accumulation of trace elements in the cold saline groundwater's of Rechitsa.

\footnotetext{
* Corresponding author: microbiol@ mail.ru
} 


\section{Materials and methods}

The objects of the study were saline groundwater's, located in the eastern part of Ussuri Bay, on the coast of Sukhodol Bay, within Partisan depression, South Primorye trough (downside area Khanka massif) $[1,2]$. Water samples were taken, observing the conditions of sterility from a self flowing borehole No. 2PR to glass bottles of $200 \mathrm{ml}$ volume in triplicate. Sampling occurred at different times of the year (July 2012, May 2013, July 2013, September 2013). Before delivery to laboratory water samples were stored in refrigerator for no more than twenty-four hours. Unstable parameters such as $\mathrm{pH}$ and temperature were measured in situ. The number of different ecological-trophic groups of bacteria was determined by the Koch method and method of limiting dilutions [5]. The groups of bacteria was determined on specially selected selective nutrient media [6]. Microorganisms were grown in a thermostat at the temperature of $25^{\circ} \mathrm{C}$. Identification of collected bacterial strains was performed based on their morphological, cultural and physiological-biochemical properties [7].

To study of the microelements absorption by microbial communities, microbial mats formed at the outlet of self-flowing highly mineralized borehole waters were sampled (July 2012). The mats samples were washed in mineral water from soils, dried and carefully ground into a fine powder for chemical analysis. After that, the biomats were subjected to microwave decomposition in closed-type systems. Chemical analysis was performed using ICP-AES and ICP-MS methods on an iCAP7600 Duo spectrometer (Thermo Scientific Corporation, USA), and Agilent 7700x spectrometer (Agilent Technologies, Japan) at the Primorsky Center for Local Elemental and Isotopic Analysis of the Far East Geological Institute, Far Eastern Branch, Russian Academy of Sciences (Vladivostok city).

\section{Results and discussion}

\subsection{Chemical composition of saline groundwaters}

The study results of physico-chemical composition carried out earlier showed that saline waters (total dissolved solids $(\mathrm{TDS})=31.8-50 \mathrm{~g} / \mathrm{L})$ are cold $\left(10.3-12.1^{\circ} \mathrm{C}\right)$, neutral $\mathrm{pH}$ (6.74-7.63) and have chloride calcium and chloride sodium - calcium composition $(\mathrm{Cl}$ 20.2-22.3 g/L). The concentration of $\mathrm{Ca}^{2+}(9.4-9.6 \mathrm{~g} / \mathrm{L})$ is two or more times higher than the concentration of $\mathrm{Na}^{+}(2.02-3.0 \mathrm{~g} / \mathrm{L})$. Waters are significantly enriched with strontium (171.5-206.8 mg/L), manganese (4.93-5.37 mg/L) and iron (0.95-1.35 mg/L) [2].

\subsection{Distribution, structure and number of ecological-trophic groups of bacteria}

Microbiological studies of underground saline waters revealed the presence of small amount of functional groups of bacteria (4-5 out of 13), as well as their low number, which averaged $1.3 \times 10^{2}$ cells $/ \mathrm{ml}(09.2013)-4.1 \times 10^{2}$ cells $/ \mathrm{ml}(07.2013)$ and their number was higher in summer periods. Similar low numbers of microorganisms of various physiological groups were noted by us earlier in various geochemical types of groundwater at the Far East of Russia [8-10]. The microflora of groundwaters was represented by various physiological groups of microorganisms carrying out the destruction of organic and mineral substances, while chemolithotrophic thionic and heterotrophic saprophytic bacteria predominated (Table 1). 
Table 1. The number of various ecological-trophic groups of bacteria in studied groundwaters.

\begin{tabular}{|c|c|c|c|c|}
\hline \multirow{2}{*}{$\begin{array}{c}\text { Dominant functional groups of } \\
\text { bacteria: }(\text { cells } / \mathbf{m l} \text { ) }\end{array}$} & \multicolumn{4}{|c|}{ Water sampling dates: } \\
\cline { 2 - 5 } & $\mathbf{0 7 . 2 0 1 2}$ & $\mathbf{0 5 . 2 0 1 3}$ & $\mathbf{0 7 . 2 0 1 3}$ & $\mathbf{0 9 . 2 0 1 3}$ \\
\hline Saprophytic bacteria $+0 \% \mathrm{NaCl}$ & 0 & 0 & 0 & 0 \\
\hline Saprophytic bacteria $+1 \% \mathrm{NaCl}$ & 0 & $1.0 \times 10^{2}$ & 0 & 0 \\
\hline Saprophytic bacteria $+3 \% \mathrm{NaCl}$ & $1.0 \times 10^{2}$ & $2.5 \times 10^{2}$ & $1.8 \times 10^{2}$ & 0 \\
\hline Saprophytic bacteria $+5 \% \mathrm{NaCl}$ & $2.3 \times 10^{2}$ & $3.4 \times 10^{2}$ & $3.1 \times 10^{2}$ & $2.0 \times 10^{2}$ \\
\hline Saprophytic bacteria $+10 \% \mathrm{NaCl}$ & $5.6 \times 10^{2}$ & $6.3 \times 10^{2}$ & $7.8 \times 10^{2}$ & $4.3 \times 10^{2}$ \\
\hline Saprophytic bacteria $+20 \% \mathrm{NaCl}$ & 0 & 0 & 0 & 0 \\
\hline Autotrophic nitrifiers & 0 & $0.2 \times 10^{2}$ & 0 & 0 \\
\hline Heterotrophic nitrifiers & 0 & $1.2 \times 10^{2}$ & 0 & 0 \\
\hline Denitrifying & 0 & $0.5 \times 10^{2}$ & 0 & 0 \\
\hline Thionic & $2.5 \times 10^{3}$ & $8.3 \times 10^{2}$ & $3.2 \times 10^{3}$ & $7.4 \times 10^{2}$ \\
\hline Sulphate-reducing & $1.2 \times 10^{2}$ & 0 & $0.7 \times 10^{2}$ & 0 \\
\hline Iron oxidizing heterotrophs & 0 & 0 & $0.1 \times 10^{2}$ & $0.3 \times 10^{2}$ \\
\hline Manganese oxidizing heterotrophs & $0.3 \times 10^{2}$ & 0 & 0 & $0.5 \times 10^{2}$ \\
\hline
\end{tabular}

The number of thionic microorganisms was high during the entire study period and reached $3.2 \times 10^{3}$ cells $/ \mathrm{ml}$, which indicates that oxidation of reduced sulfur compounds involving bacteria takes place in groundwater. The number of saprophytic microorganisms in waters varied from 0 to $7.8 \times 10^{2}$ cells $/ \mathrm{ml}$ and was higher in media with the addition of $10 \% \mathrm{NaCl}$ during the entire research period (Table 1), which may probably be due to adaptation of bacteria to a specific salt concentration in groundwater. The relatively high number of heterotrophic saprophytic bacteria noted, suggests to biological processes with releasing $\mathrm{CO}_{2}$ and can affect on gas composition of water. Among the isolated saprophytic microorganisms, gram-positive rod-shaped bacteria of the genus Microbacterium sp. significantly dominated. Also, there were noted a small number of bacteria, performing heterotrophic, autotrophic nitrification and denitrification (only in spring), sulfate reduction (only in summer) and oxidation of iron and manganese (Table 1), which indicate the participation of microorganisms in biogeochemical N, S, Fe and Mn cycles in groundwater.

\subsection{Accumulation of microelements by halophilic microbial communities forming at the outlets of saline groundwaters}

The trace element analysis of saline waters and microbial mats showed the presence of alkaline, alkaline-earth metals, transition metals, rare-earth and radioactive elements (Table 2). Highest concentrations in water had $\mathrm{Li}, \mathrm{Ba}, \mathrm{Sr}$, and also there were noted rather high content of $\mathrm{Zn}, \mathrm{Cu}, \mathrm{Ni}$ and As (Table 2). In microbial mats, high contents of $\mathrm{Sr}, \mathrm{Cu}$, $\mathrm{Zn}, \mathrm{Ba}, \mathrm{As}$ and $\mathrm{Ce}$ were detected, the concentrations of which exceeded their amount in water by $93(\mathrm{Ba})-8 \times 10^{4}$ times $(\mathrm{Ce})$ (Table 2). To evaluate biogeochemical features of elements' absorbtion by the microbial community, the coefficient of biological accumulation (CBA) was used. This coefficient calculated by the formula: 


\section{$K b=C 1 / C 2$}

where $\mathrm{Kb}$ - CBA coefficient, $\mathrm{C} 1$ - concentration of element in microbial mat, $\mathrm{C} 2$ - content of element in water. In relation to hydrobionts, it is considered, that elements are not concentrated, if $\lg \mathrm{Kb}<1$, relatively poorly accumulate, when $\lg \mathrm{Kb}<2$, are largely accumulated at $\operatorname{lg~Kb}=2-4$, and are strongly concentrated if $\lg \mathrm{Kb}>4$ [11]. Using a similar approach, we can consider the degree of accumulation of elements by saline water microbial mats.

Table 2. The trace element composition of groundwater and microbial mats, as well as the distribution of the coefficient of biological accumulation (CBA).

\begin{tabular}{|c|c|c|c|c|c|c|c|}
\hline Elements: & $\begin{array}{c}\text { Waters: } \\
\mathbf{\mu g} / \mathbf{l}\end{array}$ & $\begin{array}{c}\text { Mat: } \\
\boldsymbol{\mu g} / \mathbf{k g}\end{array}$ & $\mathbf{L g} \mathbf{C B A}$ & Elements: & $\begin{array}{c}\text { Waters: } \\
\boldsymbol{\mu g} / \mathbf{l}\end{array}$ & $\begin{array}{c}\text { Mat: } \\
\boldsymbol{\mu g} / \mathbf{k g}\end{array}$ & $\mathbf{L g} \mathbf{C B A}$ \\
\hline $\mathrm{Li}$ & 2631.22 & 4520.0 & 0.23 & $\mathrm{Ce}$ & 0.466 & 38490.0 & 4.91 \\
\hline $\mathrm{Be}$ & 0.0588 & 730.0 & 4.09 & $\mathrm{Pr}$ & 0.0781 & 3630.0 & 4.66 \\
\hline $\mathrm{Sc}$ & 1.2037 & 230.0 & 2.28 & $\mathrm{Nd}$ & 0.2621 & 13200.0 & 4.70 \\
\hline $\mathrm{V}$ & 9.632 & 3470.0 & 2.55 & $\mathrm{Sm}$ & 0.0811 & 1710.0 & 4.32 \\
\hline $\mathrm{Cr}$ & 2.522 & 11950.0 & 3.67 & $\mathrm{Eu}$ & 0.0928 & 440.0 & 3.67 \\
\hline $\mathrm{Co}$ & 0.3449 & 18300.0 & 4.72 & $\mathrm{Gd}$ & 0.0951 & 1490.0 & 4.19 \\
\hline $\mathrm{Ni}$ & 11.213 & 19450.0 & 3.23 & $\mathrm{~Tb}$ & 0.0474 & 190.0 & 3.60 \\
\hline $\mathrm{Cu}$ & 15.74 & 166320.0 & 4.02 & $\mathrm{Dy}$ & 0.0832 & 870.0 & 4.01 \\
\hline $\mathrm{Zn}$ & 58.96 & 132120.0 & 3.35 & $\mathrm{Ho}$ & 0.0431 & 170.0 & 3.59 \\
\hline $\mathrm{Ga}$ & 0.2919 & 1050.0 & 3.555 & $\mathrm{Er}$ & 0.074 & 470.0 & 3.80 \\
\hline $\mathrm{As}$ & 10.966 & 39480.0 & 3.556 & $\mathrm{Tm}$ & 0.0405 & 50.0 & 3.09 \\
\hline $\mathrm{Rb}$ & 6.37 & 9980.0 & 3.19 & $\mathrm{Yb}$ & 0.0793 & 300.0 & 3.57 \\
\hline $\mathrm{Sr}$ & 244.1 & 1210000.0 & 3.69 & $\mathrm{Lu}$ & 0.0417 & 50.0 & 3.07 \\
\hline $\mathrm{Y}$ & 1.2899 & 5420.0 & 3.62 & $\mathrm{Ti}$ & 0.05932 & 400.0 & 3.82 \\
\hline $\mathrm{Cd}$ & 0.213 & 820.0 & 3.58 & $\mathrm{~Pb}$ & 4.011 & 9460.0 & 3.37 \\
\hline $\mathrm{Cs}$ & 0.7998 & 920.0 & 3.06 & $\mathrm{Th}$ & 0.05897 & 2070.0 & 4.54 \\
\hline $\mathrm{Ba}$ & 525.62 & 49100.0 & 1.97 & $\mathrm{U}$ & 0.063 & 120.0 & 3.27 \\
\hline $\mathrm{La}$ & 0.384 & 21060.0 & 4.73 & & & & \\
\hline
\end{tabular}

Chemical elements that do not or relatively weakly concentrate in waters by microbial community are $\mathrm{Li}(0.23)$ and $\mathrm{Ba}$ (1.97) (Table 2). Such low accumulation of Li and $\mathrm{Ba}$ was noted by us earlier in the microbial communities of Kamchatka thermal waters, as well as by other authors in the microbial mats of Garginsky thermal springs [11-12]. Many metals, including heavy metals, alkaline, alkaline-earth and rare-earth elements (REE) were concentrated in microbial mats to a considerable degree, with lg CBA varying from 2.28 (Sc) to 3.82 (Ti) (Table 2). The content of elements in microbial mats ranged from 120 $\mu \mathrm{g} / \mathrm{kg}(\mathrm{U})$ to $1210000(\mathrm{Sr}) \mu \mathrm{g} / \mathrm{kg}$ and was $1900-4950$ times higher than in water. Among REEs in microbial mats, heavy REEs were largely concentrated; in ascending order of $1 \mathrm{~g}$ CBA, they can be arranged as follows: Lu (3.07), Ho (3.59), Tb (3.60), Eu (3.67), Er (3.80). In the works of Japanese colleagues, at hot springs of Nakafus (Japan) the primary accumulation in pure bacterial cultures, biofilms, and microbial mats of heavy REEs such as $\mathrm{Eu}, \mathrm{Lu}$ [13] is indicated. A study by Kazak et al. [14] reported more significant sorption of heavy REEs with pure cultures of gram-positive bacteria at $\mathrm{pH}=4$. In the table 2 are shown, that alkaline-earth element $(\mathrm{Be})$, some heavy metals $(\mathrm{Cu}, \mathrm{Co})$, radioactive $\mathrm{Th}$ and REEs, especially light $\mathrm{Pr}, \mathrm{Nd}, \mathrm{La}$ and Ce were strongly concentrated by mats. The $\lg \mathrm{CBA}$ in the mats ranged from $4.02(\mathrm{Cu})$ to $4.91(\mathrm{Ce})$. The content of light REEs in mats reached $3630.0(\mathrm{Pr})-38490.0(\mathrm{Ce}) \mu \mathrm{g} / \mathrm{kg}$, while the concentration of these elements in water was lower by 46000-82000 times (Table 2). The primary accumulation of light REEs (Ce, La, $\mathrm{Nd}, \mathrm{Pr}$ ) in microbial mats and in macrophytes of various ecological groups is also reported in the works of other authors [15-16]. A possible reason for the predominant concentration 
of light REEs in microbial mats is the formation of complex REE compounds with hydroxyl groups and phosphate containing compounds of microbial cells. High rates of metal accumulation by microbial mats are probably due to greater bioavailability of metals in water and the peculiarities of mineral metabolism of algae, due to which trace elements enter algae cells faster than they are eliminated. As a result, there is a concentration of microelements in algae biomass. The removal of elements is slowed down mostly due to the high affinity to cell walls and biopolymers of algae.

\section{Conclusions}

The obtained results have shown that the studied underground saline waters are characterized by the $\mathrm{Ca}$ prevails among cations, $\mathrm{Cl}$ dominates as anions, $\mathrm{Sr}, \mathrm{Mn}$ and $\mathrm{Fe}$ prevail among the trace elements. In groundwater, there is a small number of various physiological groups of microorganisms has been identified that are able to transform the physico-chemical composition of saline waters, participating in geochemical cycles. Chemolithotrophic thionic and heterotrophic saprophytic bacteria, developing in the presence of $10 \% \mathrm{NaCl}$, especially prevailed. In the outflow area of high TDS water from a borehole was observed the formation of microbial communities. An important role of formed microbial mats in the concentration of many heavy metals, alkaline, alkaline-earth and REEs has been shown.

This work was supported by the grant of the Russian Science Foundation № 18-17-00245.

\section{References}

1. G.A. Chelnokov, N.A. Kharitonova, M.K. Vasilieva, Rus. J. Geoecol. 4, 310-319 (2012)

2. G.A. Chelnokov, Y.V. Kolumbaeva, M.K. Vasilieva, Modern problems of hydrogeology, engineering geology and hydrogeoecology of Eurasia, all-Rus. Conf. (2015)

3. O.V. Chudaev, N.A. Kharitonova, G.A. Chelnokov, I.V. Bragin, Bull. FEB RAS, 5, 11-20 (2016)

4. V.A. Chudaeva, O.V. Chudaev, A.N. Chelnokov, W.M. Edmuns, P. Shand, Mineral waters of Primorye (chemical aspect) (Dalnauka, Vladivostok, 1999)

5. N.S. Egorov, Microbiology practical guide (MGU, Moscow,1995)

6. S.I. Kuznetsov, G.A Dubinina, Methods of studying aquatic microorganisms (1989)

7. J.C. Holt, Bergey's Manual of determinative bacteriology (1997)

8. E.G. Kalitina, N.A. Knaritonova, E.A. Vach, Modern prob. of scien. and ed., 5 (2017) Available: http://www.science-education.ru/article/view?id=26940

9. E.G. Kalitina, N.A. Knaritonova, E.A. Vach, Intern.Scien. Resear. J. 66 12-4, 26-29 (2017)

10. E.G. Kalitina, N.A. Knaritonova, E.A., T.V. Kuzmina, G.A. Chelnokov, IOP Conf. series: Earth and environ.scien. 115 (012033) (2018)

11. E.V. Lazareva, S.M. Zhmodik, I.V. Petrova et al., J. Surface. X-ray, synch. and neutr. resear. 5, 77-85 (2012)

12. E.G. Kalitina, N.A. Kharitonova, N.V. Zarubina, Ecology and safety in the technosphere: current problems and solutions, all-Rus. Scien. and Pract. Conf. (2017)

13. Y. Takahashi, X. Chatellier, K. Hattori et al., J. Chem. Geol. 219, 53-67 (2005)

14. E.S. Kazak, E.G. Kalitina, N.A. Kharitonova, Moscow Univer. Bull., ser. 4: geol. 2, 73-80 (2018) 
15. D.D. Barchutova, V.G. Budagaeva, A.V. Maligin, S.V. Zaiceva, E.V. Lavrentieva, Geological evolution of interaction of water with rocks, all-Rus. Conf. (2018)

16. E.S. Grishanceva, A.U. Bichkov, S.A. Shurupova, L.P. Phedorova, J. Proceedings of the Karelian Research Center of the RAS. 3, 55-64 (2017) 